\title{
An Investigation of the Performance of Islamic and Interest Based Banking Evidence from Pakistan
}

\author{
Tauseef KHAN, \\ University of Malakad \\ tauseefkhan392@gmail.com \\ Waqar AHMAD, \\ University of Malakand \\ waqaruom@gmail.com \\ Muhammad Khalil Ur RAHMAN, \\ Abdul Wali Khan University Mardan, Pakistan \\ Khalilhr04@gmail.com \\ Fazal HALEEM, \\ Abdul Wali Khan University Mardan, Pakistan \\ haleemfazal@gmail.com
}

\begin{abstract}
The main difference between Islamic and conventional banking is that Islamic banking works on profit and loss while conventional banking work is interest based. The aim of this research study is to measure and compare the financial performance of Islamic and conventional banking in Pakistan during 2006 to 2015. This study is to examine and to evaluate the performance of 5 Islamic banks (Meezan Islamic Bank, Bank Islami Limited, Al Baraka Islamic Bank, Dubai Islamic Bank Limited and Burj Bank Limited) and 5 conventional banks (Muslim Commercial Bank Limited, United Bank Limited, Askari Bank Limited, Allied Bank Limited, Habib Bank Limited) in terms of profitability, liquidity, risk, capital and efficiency. We used quantitative and qualitative data for comparison of Islamic and conventional banks. Collection of data consists on both primary as well as secondary sources. Primary data has been gathered from interviews and Secondary data has been gathered from the balance sheets and income statements of the sampled banks for the period of 2006 to 2015. Financial ratios such as profitability ratios, liquidity ratios, solvency ratios, capital ratios and efficiency ratios are used for measure of the financial performance of both banking sector. The results indicate that Islamic banks are less profitable, more liquid, less risky and less efficient. There is no significant difference in terms of capital between Islamic and conventional banks.
\end{abstract}

Keywords: Islamic Banks, Conventional Banks, Profitability, Liquidity, Risk, Capital, Efficiency, Financial performance, Pakistan.

JEL Classification: E5, F3, M1. 


\section{Introduction}

Financial sector plays a vital role in economic growth of any country. One of them is banking sector. It is a financial intermediary to manage funds and to channel savings and investments in financial securities (Moin, 2008). Stability and growth of economy is depending on stability of banking industry. Bank plays a role of intermediary between depositors and borrowers. Now a day's bank provides hundred of services to their customers to make their standard of living higher. It performs different function like cash management, brokerage, insurance, credit and payment facilities (Siraj and Pillai, 2012).

Islamic banking is growing well in Pakistan and other Muslim counties. State bank of Pakistan Islamic banking department is progressing with a vision to make the first choice for the users. According to an estimate the total assets of Islamic banking grown worldwide approximately US $\$ 700$ billion with annual growth exceeding $10 \%$ from last decade and to grows to US $\$ 1.6$ trillion by end of 2012. Islamic banking not only attracting people from Muslim countries but also from non Muslim major economical countries like USA, Japan, China and France (Massah and Sayed, 2015).

Islamic banking has a wide range of products and services throughout the world. Islamic banking has more than 300 financial institutions in 75 countries around the world (Suffian, 2010). Islamic financial market growth rate is considered about 15 to 20\%. Pakistan is a Muslim state trying to implement complete Islamic financial system. Islamic banking concept was started in Pakistan from 1948, when state bank of Pakistan was inaugurated. Islamic banking network is expended about over 200 branches operating in Pakistan. Assets of Islamic banks are reaching to Rs. 135 billion (Hassan, 2012).

\section{Origins of banks}

There are two types of banking interest based banking (conventional banking) and non interest banking (Islamic banking). Conventional banking was progressed in the ancient era. When the British king Henry through his orders to charge interest from operation in 1545 and allowed the Jews to charge 43 percent of interest from operation. The Jews take advantage from this situation and charge high interest in new business. The people introduced different concept to earn money with attractive interest rate. This interest concept spread all over the European countries (Awan, 2009). Conventional bank came into existence nearly 424 years ago when Banco Della pizza bank was established at Rialto in Venice (Hamoud, 1985). 
Islamic banking concept was started on the days of Holy Prophet (SAW). When interest was common in Arabian people before Islam, People used to money one another charging high interest. Interest was circulated all around but when prophet (SAW) came then life of people changed, those people that hate each other they become like a brothers (Word, 2006). When Prophet (SAW) migrated to Medina, then people of Makah also shifted his business to Medina. People shifted its profession from agriculture to business and keep their valuable asset to an honest person in the form of deposits not to earn interest. Interest concept was eliminated from people and performs different business activities on the basis of shariah. The people of Makah keep their saving with holy Prophet (SAW) because he was an honest and truthful (Awan, 2009).

Islamic bank was introduced firstly in Mit Ghamar in Egypt in 1963. In 1965 Dubai Islamic bank was established. It progressed well in a very little time. This bank practiced to present the methods of Islamic mode of finance and facilitate people through Islamic products (Chapra, 2001). In 1974 the organization of Islamic countries established IDB (Islamic Development Bank) to provide financial assistance to member countries without charging any interest. The IDB (Islamic Development Bank) is an international organization that provides the facilities only to people of Islamic counties. Islamic Bank of Sudan was established in 1977 and the same year Islamic Bank of Egypt also started their operation. In 1979 Bahrain Islamic Bank was established (Bilal and Abbas, 2015).

Islamic banking industry is growing rapidly in Pakistan. This research is to conduct the financial performance of Islamic and conventional banks in terms of profitability, liquidity, risk, capital and efficiency. Many other studies had been conducted to evaluate the financial performance of Islamic and conventional banks in Pakistan such as Moin (2008) assessed only one Islamic bank with group of 5 conventional banks during 2003-2007. Furthermore Kakakhel and Raheem (2011) evaluated the financial performance of two Islamic banks and two conventional banks for the period of 2008-2010. Moreover Usman and Khan (2012) measured the financial performance of two Islamic banks and three conventional banks for the period of 2007 to 2009. All these data were only for three or four years and Islamic banks were on initial stage in that period of time. This study is differentiating from others that no recently studies have been conducted to evaluate the financial performance of Islamic and conventional banks in Pakistan. To fill the gap time period of study increased for the accurate and authentic results. Time period of the study is ten years from 2006 to 2015 . Never done any study before for such a long period of time. 


\section{Objectives of the Study}

This study aims:

i. To investigate the performance of Islamic and interest based banking evidence from Pakistan.

ii. To analysis the financial performance of dual banking sector and try to discover that there is significant differences exists in terms of Profitability, liquidity, risk, capital and efficiency.

\section{Significance of the Study}

i. The study draws some conclusions and identifies that Islamic banks are significantly different from conventional banks. Thus it gives opportunity to the management of the banks and policy makers to take remedial action.

ii. The study is helpful for management of dual banking system to improve their management skill to bring ease of their customers in future.

iii. It helps other researchers as a source of reference and stepping stone for those who want to make further study on this area afterwards.

iv. The study will provide useful information for the creditors to make quick easy and fair decision that which banking system is better for borrowing the money.

\section{Literature Review}

Samad (1999) assessed the performance of Islamic versus conventional banks. Different financial ratios were estimated to measure efficiency. The study result signifies that BIMB (Bank Islami Malaysia Birhad) was relatively more efficient compared to conventional banks. The study also revealed that Islamic banking in Malaysia was more liquid as compared to conventional banks. In addition Bashir and Hassan (1999) measured the performance of Islamic versus conventional banks in 21 countries over the period of 1994-2001. The study measured and evaluated the performance of 43 Islamic banks in terms of profitability for the year 1994 to 2001. The result shows that Islamic banks were well capitalized. They indicated that new Islamic banks were doing well as compared to old conventional banks.

Samad and Hassan (2000) examined the performance of Islamic versus conventional banks. Analyses of the bank's performance financial ratios were 
used to determine liquidity, profitability, risk, solvency, and community involvement of BIMB (Bank Islami Malaysia Birhad). The study shows that BIMB (Bank Islami Malaysia Birhad) was relatively more liquid and less risky compares to conventional banks. Moreover they concluded that because of absence of acquainted bankers to select and manage profitable projects, in that period of time using profit sharing and joint venture loans was not widespread. Result of the primary data gathered by surveying $40 \%$ to $70 \%$ bankers identify that hat lack of knowledgeable bankers in selecting, evaluating and managing profitable project is a significant cause why Musharka and Mudarabah are not popular in Malaysia.

Iqbal (2001) compared the performance of Islamic versus conventional banks over the period of 1990-1998. The study focused to examine and to evaluate the performance of 12 Islamic banks and 12 conventional banks from the same country during the period from 1990 to 1998. Moreover financial ratios were estimated to measure these profitability (return on asset, return on equity), liquidity (cash and account with bank to total deposits), efficiency (cost to income), capital adequacy (capital to asset) and deployment (total investment to total equity, total deposits). The study indicated that Islamic banks were more profitable more liquid and more cost effective than conventional banks.

Yudistira (2003) study analyses the performance of 18 Islamic banks efficiency over the period of 1997-2000. He used frontier non-parametric approach for the judgment of efficiency level. The study concluded that Islamic banks suffer slight inefficiencies during the period of 1998-1999. The result indicates that Islamic banks shows considerable overall efficiency across the sample period. Year 2000 been the most efficient year having efficiency value (0.909) compared to $(0.902,0.870$ and 0.897$)$ for years $(1997,1998$ and 1999) respectively. In this period of time Islamic banks were suffered but they performed well as compared to conventional banks. Moreover the study suggested that inefficiency of Islamic banks was low as compared to interest based banks.

Bashir and Hassan (2004) investigated the performance of 43 Islamic banks in 21 countries over the period of 1994-2001. Financial ratios were estimated to measure these performances in terms of profitability. These ratios were net-non interest margin, before tax profit divided by total assets, return on asset, and return on equity. Finding of the study shows that controlling macroeconomic environment, taxation and financial structure, high capital and loan to assets ratio lead to higher profitability. Regression analysis shows that there is negative 
relationship implicit and explicit taxes on the measurement of bank performance, while positive relationship of favorable economic condition of bank performance measure. The result reveals that Islamic banks have well capitalized than commercial banks.

Valli and Mokhtarul (2004) compared Islamic banking schemes with pure Islamic banking schemes. The study also compared Islamic banking and conventional banking in terms of liquidity. Islamic banking has a better position in the market especially in financing or loans. Due to increased in financing and loans from Islamic banks, credit risks have a greater exposure. Islamic banking needs to monitor these risks. The study result shows that Islamic banking schemes perform better than pure Islamic banks. They also identify that Islamic banks are more liquid than interest based banks.

lqbal and Molyneux (2005) conducted to compare the financial performance of Islamic and conventional banks. The study selects 12 Islamic and 12 conventional banks. The study examined the difference between conventional and Islamic banks in terms of profitability, liquidity and efficiency. Financial ratios were used for this study such as return on assets and return on equity. The result of this study shows that Islamic banks were more profitable more liquid and better efficiency than conventional banks.

Mokhtar, et al. (2006) investigates the comparison of the efficiency of Islamic banks and conventional banks in Malaysia over the period 1997-2003. In this period of time Islamic banks have increased their assets, deposits and finance. During these periods Islamic banking has growing well and conventional banks were on his stable position. The result reveals that conventional banks efficiency was better than Islamic banks.

Hassan (2006) conducted a study on performance of Islamic banks efficiency over the period of 1995-2001. For this purpose study used cost and profit efficiency and Data Envelopment Analysis. The ratio analysis technique is used to measure the performance of Islamic banks. These ratios are return on assets and return on equity. The result shows that Islamic banks are less efficient during 1995 to 2001. Moreover it indicated that between efficiency measures like cost, technical and scale efficiency with return on assets and return on equity are highly correlated. The study found that in term of cost Islamic banks is inefficient but efficient in terms of making profit. The reason is that all the selected Islamic banks are smaller in size as compared to conventional banks.

Al-Habshi (2006) investigates the performance of Islamic and conventional banks in Malaysia over the period of 1997-2003. The study used 2 Islamic banks and 20 conventional banks to estimate the efficiency. The study used Stochastic Frontier Approach model to estimate efficiency of both banking system. Islamic 
banking industry in Malaysia has grown rapidly in terms of assets, deposits and financial basis. The result shows that during 1997 to 2003 Islamic banking efficiency was better than interest based banking.

Saleh \& Zeitun (2007) study analyses the performance of Islamic versus conventional banks in Jordan. The study focuses to evaluate the performance in terms of efficiency, profitability and investment opportunities. The study highlights the challenges being faced globally and domestically by this sector. Different test are conducting for evaluation of performance such as profit maximization, liquid and capital structure. The study found that both Islamic and conventional banks increased their efficiency but Islamic banks emphasized on short term investment and profitability. Moreover Islamic bank and conventional banks have played important role in financing project. The study also found that Islamic banking is more profitable than conventional banks.

Majid and Rulindo (2007) investigated the comparison of the performance of Islamic banks and conventional banks in Indonesia over the period 2002-2004. The study attempt to know which one of banking system in Indonesia is more efficient. For this purpose the study select two Islamic banks and 19 conventional banks. The result shows that Islamic banks are more efficient than conventional banks but selected sample size from Islamic banks were very low as compared to conventional banks.

Kader and Asarpota (2007) analyses the performance of Islamic versus conventional banks in UAE over the period of 2000-2004. This study conducted to evaluate the performance of the 3 Islamic banks and 5 conventional banks in UAE for the year 2000 to 2004. Ratios calculations have been done to measure these profitability, risk and efficiency. The results of the study show that Islamic banks are more profitable, less risky, and more efficient as compared to conventional banks. Finding show two important implications, First attributes Islamic banking profit and loss sharing paradigm is a particular reason for the growth of Islamic banking in UAE. Second Islamic banking in UAE supervised in different ways as compared to conventional banks.

Qayyum (2007) compared the performance of 20 banks in terms of efficiency for the period 1991-2005. This study used Data Envelopment Analysis (DEA) model to estimate the efficiency year by year for 15 periods. The result shows that efficiency is improving year by year such $65 \%$ in 1991 to $87.6 \%$ in 2005. This result clearly shows that banking sector improves their efficiency day by day. The result suggested that banks improved assets quality and profitability during the period of 1991 to 2005.

Masruk (2007) examined the comparison of Islamic banks and conventional banks in Malaysia over the period 2004-2008. Islamic banking industry has been 
existence in more than 30 years in Malaysia. Assets of Islamic banking in Malaysia reached to US $\$ 65.6$ billion with an annually average growth rate of 18 to $20 \%$. Islamic banking industry represented by 17 Islamic banks, 8 takaful companies and a wide range of financial products. The study evaluates financial performance in Malaysia used different financial ratios like liquidity, profitability and efficiency ratios. The study evaluates the performance in terms of profitability, liquidity and efficiency. The result reveal that Islamic banks are more liquid more efficient but less profitable than conventional banks. Profitability of conventional banks is better due to higher net financing and better asset quality.

Suffian (2007) assessed the performance of Islamic banks from Malaysia over the period of 2001-2005. In order to examine the efficiency of banks, the study used cost and profit efficiency and Data Envelopment Analysis. Using DEA efficiency measurement, the result shows that Islamic banks are less efficient during 2001 to 2005. Different results are drawn from the study. First Islamic banking in Malaysia recovered in 2003 and 2004 after declining in the year 2002. Secondly the domestic banks in Malaysia are more efficient than foreign Islamic banks. The result also found that profitability is positively correlated to all efficiency measures.

Cihak and Hesse (2008) investigated the financial performance of Islamic banks and conventional banks in 20 countries over the period 1993-2004. For this purpose they used z-scores to measure of stability of 77 interest-free banks and 397 conventional banks over the period 1993-2004. The study measure the impact of Islamic banking on financial stability. The result indicates that small Islamic banks are financially stronger than small commercial banks.

Moin (2008) assessed the performance of Meezan bank (first Islamic bank) and five conventional banks during the period 2003-07. The study measure the performance in terms of profitability (return on assets, return on equity, and profit expense ratio), liquidity (loan to deposit ratio, cash \& portfolio investment to deposit ratio, and loan to asset ratio), risk (debt to equity ratio, debt to total assets ratio and equity multiplier) and efficiency (asset utilization, income to expense, and operating efficiency) ratios of Islamic and conventional banks. The result indicates that Islamic banking is less profitable, more solvent and less efficient than conventional banks but there are no significant differences in liquidity. The reason is conventional banks have more share in financial sector and more experience than Islamic banks.

Awan (2009) analyzed that Islamic banking is growing fast and conventional banking is declining in Pakistan. Islamic banking industry reached US 1 trillion in the world at the end of 2008. The study used different financial ratios to measure the performance of Islamic and conventional banking in Pakistan. The 
study calculates financial ratios from bank financial statements and annual reports for the period of 2006 to 2008. The study selects 6 Islamic and 6 conventional banks for comparison. The results signify that Islamic banks are better in assets, deposits, financing, investments, efficiency, and quality of services and recovery of loans than conventional banks. The result of study is encouraging and predicts that Islamic banking has a bright future in Pakistan.

\section{Profitability}

Many researchers used different types of ratios to measure the profitability of dual banking sector. The profitability ratio can be used to examine the bank ability that how much earning generates. These ratios measure the firm ability to utilize it assets to create profit by deducted all costs and expenses (van Horne, 2005).

Profitability measurement is very important for every individual that is related to banking sector. The study used 12 Islamic and 12 conventional banks in terms of profitability. Moreover different types of ratios are used to show that which banking sector is better. The finding of this study shows that interest free banks are better than conventional banks in profitability (Iqbal and Molyneux, 2005). In addition Kader and Asarpota (2007) evaluate the performance of 3 interest free banks and 5 conventional banks in UAE during 2000 to 2004. Ratios calculations have been done to measure the profitability. The results of the study show that Islamic banks are better profitability as compared to conventional banks.

Olson and Zoubi (2008) compare both Islamic and conventional banking in Gulf Cooperation Council (GCC) countries during 2000-2005. The study used nonlinear techniques to evaluate the performance of both banking systems. Finding refers that interest free banks profitability are higher than interest based banks. Furthermore Ramin (2014) focuses the performance of Islamic banks versus conventional banks in two different countries during 2006 to 2011. The study selects 6 Islamic banks from Iran and 6 conventional banks from Turkey to measure the profitability. The ratios are designed to measure the profitability. The result shows that Islamic banks in Iran are more profitable than conventional banks in Turkey. In addition Erol et al (2014) investigates the comparison of the performance of Islamic banks and conventional banks in Turkey. The aims of this study to analyses the performance of the Islamic banks and conventional banks in Turkey in terms of Profitability and asset management. The result reveals that Islamic banks have better profitability and assets management than conventional banks. 


\section{Return on Average Asset}

This ratio shows earning after tax and all expenses. Higher the ratio indicates that firm will be profitable. (Van Horne, 2005). Awan (2009) measure the return on average asset and find that Islamic banks are better return on average asset than conventional banks. In addition Usman and khan (2012) investigate that ROAA of Islamic banks are better than conventional banks.

\section{Return on Average Equity}

It is shows shareholder equity after deducted all taxes and expenses (Van Horne, 2005). Awan (2009) investigates the ROAE of Islamic and conventional banks. Finding shows that interest based banks have a lower ROAE than Islamic banks. Furthermore Usman and khan (2012) concluded that conventional banks are lower ROAE than Islamic banks.

\section{Profit Expense Ratio}

It is show earnings before taxes and expenses (Samad and Hassan, 2000). Higher the ratio indicates that a firm will be more profitable. The Islamic banks have higher profit expense ratio than conventional banks (Awan, 2009). Furthermore Usman and khan (2012) find the same result. Hence we formulate our first hypothesis

$\mathrm{H}_{1}$ : Profitability of Islamic banks is more than conventional banks.

\section{Liquidity}

Liquidity ratios are used to show the bank ability to meet its financial obligations. These ratios provide a measure of bank ability that its current asset will sufficient to meet its financial obligation (van Horne, 2005).

Loghod (2007) determined the performance of Islamic versus conventional banks over the period of 2000-2005. Financial ratios were used to measure these profitability, liquidity and capital structure. The study concluded that Islamic banking was relatively less liquidity risk and didn't show any difference in profitability. Zahoor (2011) suggested that Islamic banking was more humanized as compared to interest based banking in Pakistan. The study examined the difference between conventional and Islamic banks in terms of liquidity. The result shows that liquidity of interest free banks was better than interest based banks

Usman and Khan (2012) calculated the performance of 3 interest free and 3 conventional banks during the period from 2007 to 2009. Ratios analysis techniques were used to measure these performances in terms of liquidity. The finding of the study shows that interest free banks were better liquidity than 
conventional banks. In addition Al-Hares (2013) compared the performance of interest free and interest based banking in Gulf Cooperation Council (GCC) countries. For this purpose the study select 20 Islamic and 55 conventional banks. Financial ratios were used to evaluate the performance in terms of liquidity. The result reveals that Islamic banks were more liquid than conventional banks. In addition Amba and Almukharreq (2013) measured the performance of Islamic versus conventional banks in GCC over the period of 2006-2009. The study conducted to compare the performance of 27 Islamic banks and 65 conventional banks in GCC for the year 2006-2009. Financial ratios were used for analysis of data. The study used t-test f-test and regression analysis for comparison of dual banking system in GCC region. The result indicates that liquidity of interest free banks is better than interest based banks.

\section{Loan to Asset Ratio}

It is used to analysis the liquidity of the firm in terms of deposits and total assets. Higher the ratio means that less the liquidity position of the firms (Moin, 2008). Akhter and Rehman (2009) investigate that Islamic banks are less loan to asset ratio than conventional banks.

\section{Loan Deposit Ratio}

It is measure the liquidity of the firm in terms of advances and deposits. This ratio is measure the advances and deposits rates, the lower LDR means that higher the liquidity position of the firms (Moin, 2008). Akhter and Rehman (2009), Kakakhel and Raheem (2011) investigates that Islamic banks have less LDR than conventional banks.

\section{Current Ratio}

It is used to measure the firm ability to meet its current financial obligations. The study used current ratio and find that Islamic banking performs better than conventional banks (Iqbal, 2001). Akhter and Rehman (2009) find that Islamic banks have higher current ratio than conventional banks. It shows that Islamic banks are covering its current financial obligation more efficiently than conventional banks (Kakakhel and Raheem, 2010).

\section{Current Asset Ratio}

Akhter and Rehman (2009) used current asset ratio to analyze the liquidity position of both banking system. The study finding shows that Islamic banks are higher current asset ratio than conventional banks. Furthermore Kakakhel and 
Raheem (2010) also find that Islamic banks are better in current asset ratio than conventional banks. Hence we formulate our second hypothesis

$\mathrm{H}_{2:}$ Liquidity of Islamic banks is more than conventional banks.

\section{Risk and Solvency}

Solvency ratio indicates the ability of the firm to meet its short term and long term financial obligation. This ratio calculates the bank performance that there is sufficient cash flow to fulfill its short and long term liabilities (Van Horne, 2005).

Moin (2008) applied different types of financial ratios to measure the risk and profitability of Islamic and conventional banks. The finding of study shows that Islamic banking was more solvent than conventional bank. In addition Safiullah (2010) examined the difference between conventional and Islamic banks in terms of solvency. The result found that Islamic banks were better in solvency. In the next year Masruki (2011) investigated the performance of Islamic banks in Malaysia. The ratio analysis techniques were used to measure the performance of both banking systems in Malaysia. The result shows that Islamic banks performed better during 2007-2009.

Samad and Hassan (2000) assessed the financial performance of Islamic versus conventional banks. The study concluded that BIMB (Bank Islami Malaysia Berhad) was less risky than conventional banks. Different studies found the same result that Islamic banks are less risky than conventional banks Kader and Asarpota (2007) Olson and Zoubi (2008) Akhter and Rehman (2009) Saba and Sehrish (2012) Al-Hares (2013).

\section{Debt to Equity Ratio}

Lower the ratio better for the bank. This ratio shows the financial risk of the firms. Debt to equity ratio of conventional banks is more than Islamic banks. It shows that Islamic banks are better manages their risk than conventional banks (Kakakhel and Raheem, 2010).

\section{Debt to Total Asset Ratio}

It is show the financial strength of the firms. Higher value of ratio shows that a firm is more risky. Debt to total asset ratio of Islamic banks are lower than interest based banks, it means that Islamic banks minimize their risk more efficiently than conventional banks (Moin, 2008). Akhter and Rehman (2009) also find the same result. Hence we formulate our third hypothesis.

$\mathrm{H}_{3:}$ Risk of Islamic banks is less than conventional banks. 


\section{Capital}

Capital ratio indicates the financial strength of firm. It is measure the financial risk that faces the investors (Van Horne, 2005).

Iqbal (2001) evaluated the performance of 14 Islamic banks for the period of two years. Furthermore ratios are compares such as capital adequacy ratio and deployment ratio. The result revealed that Islamic banks were well capitalized than interest based banks. In addition Siraj and Pillai (2012) investigated the comparison of the performance of Islamic banks and conventional banks in Gulf Cooperation Council (GCC) countries. For this purpose they select 6 Islamic and 6 conventional banks. Ratios analyses techniques were used to examine the performance in terms of profitability. The result shows that Islamic banks were more equity than conventional banks.

Beck et al, (2013) analyses performance of interest free banks and interest based banks during 2007-2010. The study used financial ratios to investigate the difference between both types of banking in terms of capital adequacy. The result reveals that Interest free banks have well capitalized than conventional banks. The result was similar with the study Amba and Fayza (2013) Abedifar et al, (2013) and Gazzar (2014).

\section{Capital Risk Asset Ratio}

It is used to determine capital adequacy and a technique to control risk of the firm. When value of ratio is higher it is indicate that a firm is well capitalized (Akhter and Rehman, 2009).

\section{Equity-to-Assets Ratio}

It is used to measure the financial strength of the firm. Higher the ratio indicates that firm minimizes its risk and lower the ratio its signal that a firm increase the risk failure. The Islamic banks have higher equity to asset ratio than conventional banks. It is show that Islamic banks have well capitalized than conventional banks (Hassan and Bashir, 2003). The result is similar of the previous study done by lqbal (2001).

\section{Equity Liability Ratio}

It is used to measure the capital adequacy of the firm. Higher the ratio indicates that a firm is well capitalized. Islamic banks have better equity liability ratio than conventional banks (Hassan and Bashir, 2003). Akhter and Rehman (2009) also find that Islamic banks have higher equity liability ratio than conventional banks. Hence we formulate our fourth hypothesis

$\mathrm{H}_{4:}$ Capital of Islamic banks is more than conventional banks. 


\section{Efficiency}

Conventional banking sector is a dominating sector in Bangladesh. The study investigates the performance of both banking sectors in Bangladesh. Finding refers that the efficiency of interest free banks are better than conventional banks (Akkas, 1996). In addition Samad (1999) measure the performance of interest free and interest based banking in Malaysia. Financial ratios were estimated to measure efficiency. The study result signifies that BIMB is relatively more efficient compared to conventional banks.

Al-Habshi (2006) investigated the performance of Islamic and conventional banks in Malaysia over the period of 1997-2003. The study used 2 Islamic banks and 20 conventional banks to estimate the efficiency. The study used Stochastic Frontier Approach model to estimate efficiency of both banking system. The result shows that during 1997 to 2003 Islamic banking efficiency was better than interest based banking. Moreover Qayyum (2007) used Data Envelopment Analysis (DEA) model to estimate the efficiency year by year for 15 periods. The result shows that efficiency was improved year by year such $65 \%$ in 1991 to $87.6 \%$ in 2005 . This result clearly shows that banking sector improved their efficiency day by day. In addition Saleh \& Zeitun (2007) measured the performance both banking sector in Jordan. The study focuses to evaluate the performance in terms of efficiency, profitability and investment opportunities. The result shows that both Islamic and conventional banks increased their efficiency. The result denotes that Islamic banks were more efficient than conventional banks.

\section{Asset Utilization Ratio}

It is shows that how bank are using its asset effectively. Higher ratio means that more effectively the bank utilizes its assets (Ross, Wasterfield and jaffy, 2005). Samad (1999) investigates that conventional banks have lower asset utilization ratio than Islamic banks. It is means that Islamic banks have better efficiency than interest based banks.

\section{Operating Efficiency}

It is show that how bank use its assets efficiently and effectively. Operating efficiency ratio used to minimize its assets (Widago and lka, 2008).The conventional banks has lower OE than Islamic banks. It means that interest based banks are less efficient than interest free banks (Thorsten, Asli and Quarda, 2010). Hence we formulate our fifth hypothesis

$\mathrm{H}_{5 \text { : }}$ Efficiency of Islamic banks is more than conventional banks. 


\section{Methodology}

\section{Population of the Research}

The study population is based on the whole banking sector Islamic as well as conventional banking from Pakistan.

\section{Sample of the Research}

The sample of the study is 5 conventional banks and 5 Islamic banks have been selected from Pakistan. These banks are:

\begin{tabular}{|ll|}
\hline Conventional Banks & Islamic Banks \\
\hline MCB Bank Limited & Meezan Islamic Bank \\
\hline United Bank Limited & Bank Islami Limited \\
\hline Askari Bank Limited & Al Baraka Islamic Bank \\
\hline Allied Bank Limited & Dubai Islamic Bank Limited \\
\hline Habib Bank Limited & Burj Bank Limited \\
\hline
\end{tabular}

\section{Criteria of Selection}

KPMG is an accounting firm and affiliated with KPMG international. KPMG carries financial analysis of banking on logical basis. According 2011 survey commercial banks are classified into three types in Pakistan. These are large size banks, medium size banks and small size banks on the basis of their size, assets, deposits, loans, and financing of banks. I select five large size conventional banks to compare with Islamic banks in the market. Purpose of this kind of selection is that Islamic banks are competing with large size conventional banks in a financial market.

\section{Hypotheses}

$\mathrm{H}_{1}$ : Profitability of Islamic banks is more than conventional banks.

$\mathrm{H}_{2:}$ Liquidity of Islamic banks is more than conventional banks.

$\mathrm{H}_{3:}$ Risk of Islamic banks is less than conventional banks.

$\mathrm{H}_{4:}$ Capital of Islamic banks is more than conventional banks.

$\mathrm{H}_{5}$ : Efficiency of Islamic banks is more than conventional banks. 


\section{Collection of Data}

We use quantitative and qualitative data for comparison of dual banking system in Pakistan. We collect data from both primary and secondary sources.

\section{Primary Data}

Primary data has been gathered from interview. Twenty four interviews have been conducted from managers of Islamic and conventional banks, and then thematic analysis applied for judgment of qualitative data.

\section{Secondary Data}

Secondary data collect from financial statement of the selected banks for selected time period.

\section{Analyses Tools}

The analysis of the data we used ratio analysis technique for quantitative data and thematic analysis for qualitative data to determine the financial performance of banks.

\section{Time Period}

In this study we compare financial performance of both banking systems in Pakistan during the period of 2006 to 2015.

\section{Profitability Ratios}

Iqbal (2001) evaluate the profitability of both banking systems by using two types of ratios. These ratios are rate of return on assets and the rate of return on equity. The result indicate that Islamic banks are well profitable than conventional banks. In addition Samad and Hassan (1999) measure the performance of three types of profitability ratios of Islamic banking in Malaysia. These ratios are ROAA (return on avg assets), ROAE (return on avg equity) and PEM (profit expense margin) ratio. Akhter and Rehman (2009) used three types of ratios to measure the performance of Islamic and conventional banks. These ratios are return on average assets (ROAA), return on avg equity (ROAE) and profit expense margin (PEM) ratio. Kakakhel and Raheem (2011) used five types of profitability ratios to measure the performance of dual banking system. The result shows that interest based banks are better than interest free banks in terms of profitability. 


\begin{tabular}{|l|l|}
\hline \multicolumn{1}{|c|}{ Variable } & Formula \\
\hline 1. Return on average assets & Earnings after tax/Average assets \\
\hline 2. Return on average equity & Earnings after tax/Average equity \\
\hline 3. Return on assets & Earnings after tax/Total assets \\
\hline 4. Return on equity & Earnings after tax/Total equity \\
\hline 5. Profit Expense Margin & Profit before tax/operating expense \\
\hline 6. Net Profit Margin & Net Income/ Sales \\
\hline
\end{tabular}

\section{Liquidity Ratios}

Iqbal (2001) used current ratio to evaluate the performance of Islamic and conventional banks. The result shows that Islamic banking is more liquid than conventional banks. Kakakhel and Raheem (2011) evaluate the liquidity position of interest free and interest based banks by using four types of ratios. These ratios are current ratio, cash ratio, networking ratio, and advances to deposits ratio. The result indicates that Islamic banks are more liquid than conventional banks. Samad and Hassan (1999) used three types of ratios to evaluate the liquidity of dual banking system. These ratios are current ratio, current asset ratio and loan deposit ratio. Akhter and Rehman (2009) used current ratio, loan asset ratio, loan deposit ratio and net loan total asset ratio. The result of the study shows that interest free banks are better liquidity than conventional banks.

\begin{tabular}{|l|l|}
\hline Variable & Formula \\
\hline 1. Current Ratio & Cash and account with bank/Total Deposits \\
\hline 2. Loan Deposit Ratio & Loans/ Deposits \\
\hline 3. Investment to Total Assets & Investments/Total assets \\
\hline 4. Deposit Total Asset Ratio & Deposit/Total assets \\
\hline
\end{tabular}

\section{Solvency Ratios}

Kakakhel and Raheem (2011) evaluate the solvency of Islamic and conventional banking by using three types of ratios. These ratios are leverage ratio, debt to asset ratio, and debt to equity ratio. Samad and Hassan (1999) used three types of ratios to calculate the risks and solvency of dual banking system. These ratios are debt to equity ratio, debt to total asset ratio and loan deposit ratio. The finding refers that interest free banks are less risky than conventional banks. Akhter and Rehman (2009) used three types of ratios to measure the performance of Islamic versus conventional banks. These ratios are debt equity ratio, debt to total asset ratio and loan deposit ratio. The result indicates that Islamic banking is less risky than conventional banks. 
1. Debt Equity Ratio Total Debt / Shareholder Equity

2. Debt to total asset ratio

Total Debt/ Total asset

\section{Capital Ratios}

Iqbal (2001) used capital asset ratio to evaluate the capital structure of Islamic and conventional banks. Hassan and Bashir (2003) also used capital asset ratio to analysis the performance of dual banking system.

\begin{tabular}{|l|l|}
\hline Variable & Formula \\
\hline 1. Equity/Liabilities ratio & Average equity/ Average liabilities \\
\hline 2. Equity/Asset ratio & Average equity/ Average assets \\
\hline 3. Capital Ratio & Total equity/ Total asset \\
\hline 4. Deposit/Equity Ratio & Total Deposit/Total Equity \\
\hline
\end{tabular}

\section{Efficiency Ratios}

Iqbal (2001) evaluate the efficiency of interest free and interest based banks used cost to income ratio. In addition Samad and Hassan (1999) used thirteen ratios to judge the efficiency of both type of banks. Bader and Shamsher (2007) evaluate the efficiency of Islamic and interest base banks. Akhter and Rehman (2009) used also used different financial ratios such as net interest margin and cost to income ratio.

\begin{tabular}{|l|l|}
\hline Variable & Formula \\
\hline Asset Utilization & Total Revenue / Total Assets \\
\hline Net Interest Margin & Total Interest Income - Total interest expense/Total Assets \\
\hline Operating Efficiency & Total Operating Expenses / Total Operating Revenue \\
\hline
\end{tabular}

\section{Quantitative Analysis and Result}

In quantitative analysis the ratios are calculated from financial statement of selected banks. The financial statement collected from official websites of selected banks and official website of state bank of Pakistan. To evaluate the performance different types of ratios are used in terms of profitability, liquidity, risk, capital and efficiency. Yearly ratios of Islamic banks are compared with yearly ratios of conventional banks. Moreover combined mean of profitability, liquidity, risk, capital and efficiency ratios of Islamic banks are compared with combined mean of conventional banks. The study will apply t-test to test the 
difference between mean ratios of Islamic and conventional banks. This $t$ test have been performed using Microsoft excel.

Table 1 Statistics for Banks from 2006 to 2015 in terms of profitability

\begin{tabular}{llllll}
\hline Banks & Ratios & Mean & SD & T-value & P-value \\
\hline Islamic banks & $\begin{array}{l}\text { Return on average } \\
\text { assets }\end{array}$ & 0.0031 & 0.013607 & 1.53142 & 0.1642 \\
$\begin{array}{l}\text { Conventional } \\
\text { banks }\end{array}$ & $\begin{array}{l}\text { Return on average } \\
\text { assets }\end{array}$ & 0.04664 & 0.062101 & & \\
$\begin{array}{l}\text { Islamic banks } \\
\text { Return on average } \\
\text { equity }\end{array}$ & 0.02438 & 0.094821 & 4.268455 & 0.00273 \\
$\begin{array}{l}\text { Conventional } \\
\text { banks }\end{array}$ & $\begin{array}{l}\text { Return on average } \\
\text { equity }\end{array}$ & 0.23234 & 0.05364 & & \\
$\begin{array}{l}\text { Islamic banks } \\
\text { Return on Asset }\end{array}$ & -0.00086 & 0.007893 & 3.582085 & 0.007166 \\
\hline $\begin{array}{l}\text { Conventional } \\
\text { banks }\end{array}$ & Return on Asset & 0.01728 & 0.00812 & & \\
\hline
\end{tabular}

\begin{tabular}{llllll} 
Islamic banks & Return on equity & 0.00016 & 0.113877 & 3.104148 & 0.014574 \\
$\begin{array}{l}\text { Conventional } \\
\text { banks }\end{array}$ & Return on equity & 0.1851 & 0.069137 & & \\
$\begin{array}{l}\text { Islamic banks } \\
\text { Profit Expense }\end{array}$ & -0.03146 & 0.412494 & 3.465578 & 0.008498 \\
$\begin{array}{l}\text { Margin } \\
\text { Conventional } \\
\text { banks }\end{array}$ & $\begin{array}{c}\text { Profit Expense } \\
\text { Margin }\end{array}$ & 1.18616 & 0.668634 & & \\
\hline
\end{tabular}

\begin{tabular}{llllll}
\hline Islamic banks & Net Profit Margin & -0.02544 & 0.118345 & 3.781962 & 0.005373 \\
\hline $\begin{array}{l}\text { Conventional } \\
\text { banks }\end{array}$ & Net Profit Margin & 0.2508 & 0.11256 & & \\
\hline
\end{tabular}

$P$ value of $(p<0.05)$ refer to statistical significant at $5 \%$ level respectively

Table 1 present comparative performance of Islamic and conventional banks in terms of profitability over the period of 2006 to 2015. The study analyses profitability by using different types of ratios like return on average assets, return on average equity, return on assets, return on equity, profit expense margin and net profit margin. The table 1 shows mean of ratios of both Islamic and conventional banks. 
The mean value of return on average asset (ROAA) is $0.31 \%$ for Islamic banks which is lowere as compared to $4.64 \%$ of conventional banks. The higher ROAA show that efficiently the firm utilizes its assets. The result indicate that Islamic banks generate return of $0.31 \%$ for every rupees while conventional banks generate return of $4.64 \%$ for every rupees which show clear difference that conventional banks have better ROAA than Islamic banks. The return on average equity shows the profit that generated from shareholder investment. The table shows that mean value of return on average equity (ROAE) is $2.43 \%$ for Islamic banks which is lower than compared to conventional banks $23.23 \%$. The ROA and ROE for Islamic banks is $-0.08 \%$ and $0.016 \%$ compared to conventional banks is $1.73 \%$ and $18.51 \%$ which indicate that both ROA, ROE for conventional banks are better than Islamic banks. Profit expense margin ratio means that making high profit with a given expense. The table shows that mean value of profit admin expense margin for Islamic bank is $-3.14 \%$ is lower than conventional banks which is $118.62 \%$. Net profit margin is $-2.54 \%$ for Islamic banks while for conventional banks is $25.08 \%$. The net profit margin ratio is lower for Islamic banks to compared conventional banks due to risk sharing system. The overall result shows that all six profitability ratios of conventional banks are better than Islamic banks. T test shows that return on average assets is not significantly different at $5 \%$ of significance and remaining five profitability ratios are significantly different at $5 \%$ level of significant. We can conclude that profitability of Islamic banks are lower than interest free banks. The result is similar with other literature (Kakakhel and Raheem (2011), Hamedian (2013), Hasan and Dridi (2010), Masruki (2007), Metwally (1997), Moin (2008), Jaffar and Manarvi (2011)).

Table 2 Statistics for Banks from 2006 to 2015 in terms of liquidity

\begin{tabular}{llllll}
\hline Banks & Ratios & Mean & SD & T-value & P-value \\
\hline $\begin{array}{l}\text { Islamic } \\
\text { banks }\end{array}$ & Current Ratio & 0.2644 & 0.146103 & 3.78389 & 0.002283 \\
$\begin{array}{l}\text { Conventional } \\
\text { banks }\end{array}$ & Current Ratio & 0.11818 & 0.03997 & & \\
$\begin{array}{l}\text { Islamic } \\
\text { banks }\end{array}$ & Loan Deposit Ratio & 0.58566 & 0.130747 & 0.245836 & 0.811999 \\
$\begin{array}{l}\text { Conventional } \\
\text { banks }\end{array}$ & Loan Deposit Ratio & 0.60012 & 0.014286 & & \\
$\begin{array}{l}\text { Islamic } \\
\text { banks }\end{array}$ & $\begin{array}{l}\text { Investment to Total } \\
\text { Assets }\end{array}$ & 0.25536 & 0.041929 & 4.249937 & 0.002799 \\
\hline
\end{tabular}




\begin{tabular}{llcccc}
\hline $\begin{array}{l}\text { Conventional } \\
\text { banks }\end{array}$ & $\begin{array}{l}\text { Investment to Total } \\
\text { Assets }\end{array}$ & 0.35478 & 0.031277 & \\
$\begin{array}{l}\text { Islamic } \\
\text { banks }\end{array}$ & $\begin{array}{l}\text { Deposit Total Asset } \\
\text { Ratio }\end{array}$ & 0.76606 & 0.057932 & 0.829695 & 0.430771 \\
$\begin{array}{l}\text { Conventional } \\
\text { banks }\end{array}$ & $\begin{array}{l}\text { Deposit Total Asset } \\
\text { Ratio }\end{array}$ & 0.79098 & 0.033976 & \\
\hline \multicolumn{4}{l}{$P$ value of $(p<0.05)$ refer to statistical significant at 5\% level respectively }
\end{tabular}

Table 2 describes the performance of Islamic and conventional banks in terms of liquidity over the period of 2006 to 2015. The analysis of liquidity using different types of ratios such as current ratio, loan deposit ratio, investment to total assets ratio and deposit to total asset ratio. Table 2 shows mean of different types of ratio of both Islamic and conventional banks.

The mean value of current ratio of Islamic banks is $26.44 \%$ while conventional banks are $11.82 \%$. Higher the current ratio means the bank has more liquid assets for depositors to pay back. Islamic bank is better than conventional banks in terms of current ratio. In terms of loan deposits ratio mean value of Islamic banks is $58.57 \%$ while conventional banks are $60.01 \%$ which means higher the loan deposits ratio more the bank relying on borrowing funds. A higher the loan deposits ratio show less liquidity of the bank. The result from the table 2 indicates that Islamic banks are better in loan deposits ratio compares to conventional banks. Investment to total assets ratio for Islamic banks are $25.54 \%$ while for conventional banks are $35.48 \%$. The mean value of deposits to total assets ratio of Islamic banks are $76.61 \%$ while conventional banks are $79.10 \%$. A higher the deposits to total assets ratio means the bank is less liquid so Islamic banks are better in terms of deposits to total assets ratio than conventional banks. All the four liquidity ratios of Islamic banks are better than conventional banks. The result of $t$ test shows that investment to total assets and current ratios are significantly different at $5 \%$ level of significant. The result supports the hypothesis that Islamic banks are more liquid than conventional banks. The result is similar with the literature of Akhter and Rehman (2009), Jaffar and Manarvi (2011), Usman and Khan (2012).

Table 3 Statistics for Banks from 2006 to 2015 in terms of risk

\begin{tabular}{llllll}
\hline Banks & Ratios & Mean & SD & T-value & P-value \\
\hline Islamic banks & Debt Equity Ratio & 8.78876 & 3.887818 & 1.478654 & 0.017492 \\
$\begin{array}{l}\text { Conventional } \\
\text { banks }\end{array}$ & Debt Equity Ratio & 12.61638 & 4.288204 & & \\
& & & & & \\
\end{tabular}


HOLISTICA Vol 9, Issue 1, 2018

\begin{tabular}{llllll}
\hline Islamic banks & $\begin{array}{l}\text { Debt to total } \\
\text { asset ratio }\end{array}$ & 0.50476 & 0.123479 & 2.120245 & 0.0068 \\
$\begin{array}{l}\text { Conventional } \\
\text { banks }\end{array}$ & $\begin{array}{l}\text { Debt to total } \\
\text { asset ratio }\end{array}$ & 0.90582 & 0.032457 & \\
\hline \multicolumn{2}{c}{$P$ value of $(p<0.05)$ refer to statistical significant at 5\% level respectively }
\end{tabular}

Table 3 present comparative performances of interest free and interest based banks in terms of risk over the period of 2006 to 2015. To identify that which banks are more risky by using different types of ratios such as debt equity and debt to total asset ratio. Table 3 shows mean of different types of ratio of Islamic and conventional banks.

Debt to equity and debt to assets ratio show the financial strength of the bank. A lower value of debt to equity and debt to asset ratios are better for the bank. Debt to equity, debt to asset for Islamic banks are $878.8 \%, 50.48 \%$ while for conventional banks are $1261.63 \%, 90.58 \%$. Both these ratios show that Islamic banks are less risky than conventional banks. We accept the hypothesis that Islamic banks are less risky than conventional banks. The reason is debt to equity and debts to asset ratio are significantly different at $5 \%$ level of significant. The result is similar with literature of Samad and Hassan (1999), Olson and Zoubi (2008), Beck et al. (2013), Massah and sayed (2015).

Table 4 Statistics for Banks from 2006 to 2015 in terms of Capital

\begin{tabular}{|c|c|c|c|c|c|}
\hline Banks & Ratios & Mean & SD & T-value & P-value \\
\hline Islamic banks & $\begin{array}{l}\text { Equity/Liabilities } \\
\text { ratio }\end{array}$ & 0.131 & 0.080969 & -0.0554 & 0.957181 \\
\hline $\begin{array}{l}\text { Conventional } \\
\text { banks }\end{array}$ & $\begin{array}{l}\text { Equity/Liabilities } \\
\text { ratio }\end{array}$ & 0.1272 & 0.130272 & & \\
\hline Islamic banks & Equity/Asset ratio & 0.1078 & 0.049621 & 0.10923 & 0.21846 \\
\hline $\begin{array}{l}\text { Conventional } \\
\text { banks }\end{array}$ & Equity/Asset ratio & 0.0742 & 0.026508 & & \\
\hline Islamic banks & Capital Ratio & 0.13948 & 0.068705 & -1.86403 & 0.099314 \\
\hline $\begin{array}{l}\text { Conventional } \\
\text { banks }\end{array}$ & Capital Ratio & 0.07868 & 0.024478 & & \\
\hline Islamic banks & $\begin{array}{l}\text { Deposit/Equity } \\
\text { Ratio }\end{array}$ & 8.20428 & 3.145968 & 1.488887 & 0.174842 \\
\hline $\begin{array}{l}\text { Conventional } \\
\text { banks }\end{array}$ & $\begin{array}{l}\text { Deposit/Equity } \\
\text { Ratio }\end{array}$ & 11.51158 & 3.843732 & & \\
\hline
\end{tabular}

$P$ value of $(p<0.05)$ refer to statistical significant at $5 \%$ level respectively 
Table 4 describes the performance of Islamic and conventional banks in terms of capital over the period of 2006 to 2015. The study analysis the capital using different types of ratios such as equity liability, equity asset, capital ratio and deposit equity ratio. Equity liability ratio used to measure the capital adequacy of the firm. Higher the ratio indicates that a firm is well capitalized. The mean value of equity liability ratio for Islamic banks is $13.10 \%$ while for conventional banks are $12.72 \%$. The analysis shows that no major differences between both types of banking in terms of equity liability ratio. Equity asset ratio of Islamic banks is $10.78 \%$ against the conventional banks are $7.42 \%$ which show that Islamic banks are better in equity asset ratio. Capital ratio shows the bank capacity to sustain losses of assets. A higher of the ratio means that greater capacity for a bank to absorb assets losses. The capital ratio for Islamic banks is $13.94 \%$ as compared to conventional banks are $7.87 \%$ which show that Islamic banks performance better than conventional banks in terms of capital ratio. Deposit equity ratio of Islamic banks is $820.42 \%$ as compared to conventional banks are $1151.15 \%$. Deposit equity ratio of conventional banks is better than Islamic banks.

Overall result shows that Islamic banks are better in terms of equity liability and equity asset ratio than conventional banks but we cannot accept the hypothesis that Islamic banks are well capitalized than conventional banks. The reason is that all four ratios are not significantly different at $5 \%$ level of significant. The result is similar with the literature Jaffar and Manarvi (2011).

Table 5 Statistics for Banks from 2006 to 2015 in terms of Efficiency

\begin{tabular}{llllll}
\hline Banks & Ratios & Mean & SD & T-value & P-value \\
\hline $\begin{array}{l}\text { Islamic } \\
\text { banks }\end{array}$ & Asset Utilization & 0.03742 & 0.013452 & 0.715865 & 0.494437 \\
$\begin{array}{l}\text { Conventional } \\
\text { banks }\end{array}$ & Asset Utilization & 0.043 & 0.011083 & & \\
$\begin{array}{l}\text { Islamic } \\
\text { banks }\end{array}$ & $\begin{array}{l}\text { Net Interest } \\
\text { Margin }\end{array}$ & 0.09038 & 0.043696 & -2.38146 & 0.012794 \\
$\begin{array}{l}\text { Conventional } \\
\text { banks }\end{array}$ & $\begin{array}{l}\text { Net Interest } \\
\text { Margin }\end{array}$ & 0.06282 & 0.007385 & & \\
\hline
\end{tabular}

\begin{tabular}{llllll}
$\begin{array}{l}\text { Islamic } \\
\text { banks }\end{array}$ & $\begin{array}{l}\text { Operating } \\
\text { Efficiency }\end{array}$ & 0.54636 & 0.101666 & -5.23212 & 0.000791 \\
$\begin{array}{l}\text { Conventional } \\
\text { banks }\end{array}$ & $\begin{array}{l}\text { Operating } \\
\text { Efficiency }\end{array}$ & 0.29006 & 0.04077 & & \\
\hline
\end{tabular}

$P$ value of $(p<0.05)$ refer to statistical significant at $5 \%$ level respectively 
Table 5 present the comparison of Islamic and conventional banks in terms of efficiency over the period of 2006 to 2015. Analysis of efficiency the study used different types of ratios like asset utilization, net interest margin and operating efficiency. Asset utilization ratio show that how the bank using its asset effectively. The higher ratio means that more effectively the bank utilizes its assets. The mean value of asset utilization ratio for Islamic banks is $3.74 \%$ and for conventional banks are $4.30 \%$. Net interest margin value for Islamic banks is $9.04 \%$ and for conventional banks are $6.28 \%$. A higher net interest margin value indicates that a bank will be more efficient. There is significant difference between Islamic and conventional banks in terms of net interest margin ratio at $5 \%$ level of significant.

Operating efficiency ratio show that control operating expenses and generate operating revenue which means that lower the value efficiently manage their operating expenses. Mean value of operating efficiency ratio is $54.64 \%$ for Islamic banks while for conventional banks are $29.01 \%$. The result indicates that conventional banks are better in terms of operating efficiency. The overall result shows that net interest margin and operating efficiency ratios are significantly different at $5 \%$ level of significant. The result shows that Islamic banks are less efficient than conventional banks. The result is similar with the literature of Suffian (2007), Alhabshi (2007), Srairi (2010), Hanif, Tariq and Tahir (2012).

\section{Conclusions}

I have done quantitative and qualitative analyses to meet the objective of study. The objective of the study is to compare financial performance of Islamic and conventional banks. In the light of quantitative and qualitative analysis the study concludes that Islamic banks are less profitable than conventional banks. The analysis shows that the higher profitability of conventional banks is due to a wide network as compared to Islamic banks. The analysis shows that conventional banks have better than Islamic banks in terms of return on average asset and return on average equity ratio. Islamic banks ROA (Return on asset) and ROE (Return on equity) are less than as compared to conventional banks. The result indicates that ROA, ROE are in favor of conventional banks due to wide shares in financial market. Profit expense margin and net profit margin is also better for conventional banks. The study concludes that conventional banks are better to manage their assets and effectively generate the income from existing assets.

Current ratio of Islamic banks is more than conventional banks. It is indicate that the bank has more liquid assets for depositors to pay back. In terms 
of loan deposits ratio Islamic banks are better than conventional banks, it shows that banks are more relying on borrowing funds. A higher the loan deposits ratio show less liquidity of the bank. Furthermore Islamic banks are better in terms of investment to total assets and deposits to total assets ratio. Islamic banking liquidity is higher due to a limited investment as compared to conventional banking that maximizes their investment without any restriction and invests everywhere as they like. Through quantitative and qualitative analysis we conclude that Islamic banks depositors are secure because they have enough cash to pay back to their depositors.

The study concludes that Islamic banking is less risky due to interest rate of conventional banking. The conventional banking offer low interest and give those funds to needy people at high interest rate. These funds are fixed rate as compared to Islamic banking their income is sharing on profit and loss based. Debt to equity and debt to asset for Islamic banks are better than conventional banks. The results of these ratios indicate that Islamic banks are less risky than conventional banks. The analysis of the study shows that Islamic banks are more financing an equity rather than debt. There is no significant difference in terms of capital between Islamic and conventional banks. The reason is all capital ratios are not significantly different at $5 \%$ level of siginificant.

The result from the analyses shows that Islamic banks are less efficient as compared to conventional banks in different resources such as skillful employees, modern technology and better internal efficiency. The conventional banking has provided fast and efficient services then Islamic banks. They offer different products to fulfill the customer need more efficiently. To measure efficiency of Islamic and conventional banks by using different ratios in quantitative analysis like asset utilization and operating efficiency ratio. Asset utilization ratio means that how the bank utilize its assets more effectively, The value of asset utilization ratio for Islamic banks is less than conventional banks .The operating efficiency ratio means that how to control operating expenses and generate revenue from operation. The analyses shows that conventional banks are efficiently manage their expenses. The overall result signifies that Islamic banking efficiency is less than conventional banks.

Limitation of the study that is only targeted Pakistani banking sector due to shortage of time. This research is limited to five Islamic and five conventional banks over the period of ten years. In future the sample size should increase to produce more accurate result. In the future for better result increase the number of banks, Islamic as well as conventional banks and include other countries to generalize the result on the whole world. In future conduct the studies time to time because Islamic banking is an introductive stage in Pakistan. The research is 
limited to compare financial performance based on nineteen ratios divided into five categories such as profitability, liquidity, risk, capital and efficiency. This gives opportunities for future studies to conduct a research take other financial ratios for comparison of interest free and interest base banks.

This study provides new ideas for future studies.

Why Islamic banks are not effectively manages their assets to generate profit from existing assets than conventional banks?

Why conventional banks are more relying on debt financing than Islamic banks?

\section{References}

[1] Aggarwal, R. K., \& Yousaf,T. (2000). "Islamic Banks and Investment Financing" Journal of Money, Banking, and Credit. Vol. 32(1) pp. 93-120.

[2] Ahmad, M. F., Hussain, M. S. \& Hannan, S.A. (1999). "Experiences in Islamic Banking: A Case Study of Islamic Bank Bangladesh Dhaka" Institute of Policy Studies.Vol.5(9) pp. $57-82$.

[3] Akhter, S. \& Rehman, N,S. (2009). "Comparative analysis of liquidity position of banks" Daffodil International University Journal of Business and Economics.Vol. 7(1) pp. $123-148$.

[4] Akhtar, M.F., \& Sadaqat, S. (2011). "Liquidity Risk Management: A Comparative Study Between Conventional and Islamic Banks of Pakistan" Interdisciplinary Journal of Research in Business, Vol 1(1) pp. 35-44.

[5] Akkas, A. (1996). "Relatively Efficiency of Conventional and Islamic Banks in Dhaka" Journal of Research in Business.

[6] Al Habshi, S. (2006). "Efficiency of Islamic banks in Malaysia a stochestic frontier approach". Journal of economics corporation among Islamic counrtries, . Vol. 27(2) pp. 37-70.

[7] Al Hares, H. (2013). "Financial Performance of Islamic banks and Conventional Banks with basel III capial standard". Journal of applied resrearch in business,. Vol. 29(4) pp. 1031-1048.

[8] Alimshan, F. (2010). " Comparison of Islamic and conventional banking in terms of profitability". Journal of Islamic,Banking and Finance, Vol 4(1) pp. 31-56.

[9] Iqbal, A. J. \& Molyneux, P., (2007). "Efficiency in Arabian Banking" Jordan journal of business administration. Vol 3(3) pp $373-360$.

[10] Alkassim, F. (2005). "The profitability of Islamic and conventional banking in the GCC countries" Journal of Review of Islamic Economics, Vol.4(13) pp. 5-30. 
[11] Abidifar, T. Pejman, K. Philip, C. Molyneux, I. \& Tarazi,A,. (2013). "Risk and stability of Islamic banking Using thematic analysis in psychology" A cross country empirecal investigation Vol 2(1) pp 25-41.

[12] Amba,S.M \& Almukharreq.F (2013). "Impact of Financial crisis on profitability of Islamic vs conventional Banks- Evidence from GCC" International Journal of Financial Research $R$ Vol.4(3.

[13] Ansari, S,. \& Rehman, A. (2011). "Financial Performance of Islamic and Conventional Banks in Pakistan: A Comparative Study" Paper presented at the 8th International Conference on Islamic Economics and Finance. Vol.1(1) pp. 1 19.

[14] Awan, A.G. (2011). "Comparison of Islamic and conventional banking in Pakistan" A proceed $2^{\text {nd }}$ CBRC Lahore.

[15] Bader, M.K., Mohamad, S, Ariff, M \& Hassan, T (2008). “Cost, revenue and profit efficiency of Islamic versus conventional banks: international evidence using DEA" Islamic Economic Studies, Vol 15(2) pp. 23-76.

[16] Bashir, K.M., \& Mohammad, S. (2007). "Cost, Revenue, and Profit efficiency of Islamic versus Conventional banks" Journal of Islamic economics, banking and finance Vol.4(2) pp 107- 130.

[17] Bashir, M. (2003). "Assessing the performance of Islamic Banks" Some evidence from the Middle East, Islamic Economic Studies, Vol 11 pp 31-60.

[18] Bashir, M. \& Hassan, T. (1999). "Risk and profitability measures in Islamic Banks" The case of two Sudanese banks Islamic Economic Studies. Vol 6(2) pp 1-24.

[19] Beck, T. (2010). "Islamic Vs Conventional Banking Business Model" Efficiency and Stability, Journal of Banking and Finance Vol 37 (2013) pp. 433-447.

[20] Bilal, M. \& Abbas. M. (2015). "Islamic Vs Conventional Banking A Comparative study" Journal of Busines Research Vol 5 (3) pp. 72-94.

[21] Botis, S. (2013). "Shariah concepts in Islamic banking" Journal of economic sciences Vol 6(5) pp 140-148.

[22] Braun,V. \& Clark,V,. (2006). "Using thematic analysis in psychology" Qualitative research in psychology $\mathrm{Vol} 3(1)$ pp 77-101.

[23] Chapra, M,. (2001). "What is Islamic economics" International journal of business and management Vol 9(1) pp 173-191.

[24] Cihak, M. \& Hesse, H,. (2010). "Islamic Banks and Financial Stability" An Empirical Analysis, Journal of Financial Services Research, Vol 38 (3) pp 95-113.

[25] Erol, C. Hassan. F. \& Tunc, G,. (2014). "Performance comparison of Islamic Banks and Commercial banks in Turkish banking" Journal of business, Vol 9 (2) pp 114-128. 
[26] Essayyad, M,. and Madani, H,. (2003) "Investigating Bank Structure of an Open Petroleum Economy" The Case of Saudi Arabia. Managerial Finance, Vol 2(9) pp 73 - 92.

[27] Farrukh, Z. (2006). "Corporative Performance of Islamic and Commercial Banks in Karachi" College of Management Sciences, PAF-Karachi Institute of Economics \& Technology.

[28] Fayed, M. (2013). "Comparative performance study of conventional and Islamic banking in Egypt" Journal of Applied Finance \& Marketing Vol 3(2) pp 1 - 14.

[29] Gazzar, M. (2014). "Financial Performance of Islamic and Conventional Banks in GCC and MENA region, A Comparative Study"

[30] Hamid,M. \& Azmi,H,. (2011). "The performance of banking in Malaysia" Internatinla journal of economics and management sciences Vol 1(1).

[31] Hanif, M. (2011). "Differences and Similarities in Islamic and Conventional Banking" International Journal of Business and Social Science, Vol 2(2) pp 166175.

[32] Haron, S,. (2000). "A Comparative Study of Islamic Banking Practices" Journal of Islamic Economic, Vol 10 (1) pp. 1-31.

[33] Hasan, M,. and Dridi, J. (2010). "The Effects of the Global Crisis on Islamic and Conventional Banks" A Comparative Study; IMF Working Paper, WP/10/201.

[34] Hassan, T. (2012). "Customer perception regarding car loans in Islamic and Conventional Banks" International journal of learning and development. Vol 2(6) pp175-185.

[35] Hassan, M,. (2006). "Development and Performance of Domestic and Foreign Banks in the GCC Countries" Journal of Managerial Finance, 29, pp.42-72.

[36] Homoud, S. H . (1985). "Islamic banking, Arabian information Ltd at London" International Journal of business.

[37] Iqbal, M,. (2001). "A Comparative Study. M. Iqbal, Islamic Banking and Finance: Current Development in Theory and Practice, United Kingdom" The Islamic Foundation, Islamic and Conventional Banking. Vol 8(2) pp 1-27.

[38] Iqbal, M. (2012). "Liquidity of risk management a comparative study of Islamic banks and Conventional Banks of Pakistan". Global journal of resrearch in business, Vol. 12(5) pp. 211-225.

[39] Iqbal, M. and Molyneux, P. (2005). "Thirty Years of Islamic Banking, History, Performance and Prospects" New York Palgrave Macmillan.

[40] Islam, M. M, \& Chowdhury, M. (2009). "A Comparative Study of Liquidity Management of an Islamic Bank and a Conventional Bank" The Evidence from Bangladesh. Journal of Islamic Economics, Banking and Finance, Vol. 5(1).

[41] Jaffar, M., \& Manaravi, I. (2011) "Performance Comparison of Islamic and Conventional Banks in Pakistan." Global Journal of Management and Business Research, Vol. 11(1), pp. 61-66. 
[42] Johnes, J. Izzeledin, M. \& Pappas, V. (2008) "Performance Comparison of Islamic and Conventional Banks in terms of Efficiency." Journal of Economic Literature, Vol. 6(1), pp. 1-45.

[43] Kader, j.M., \& Asarpota, A, K. (2007). "Comparative Financial Performance of Islamic vis-à-vis Conventional Banks in the UAE". International Review of Business Research Papers, Vol. 5(3) pp. 189-201.

[44] Kakakhel, J. S,. Raheem, F. \& Tariq, M. (2011). "A Study of Performance Comparison between Conventional and Islamic Banking in Pakistan" Abasyn Journal of Social Sciences Vol.6(2) pp. 91 - 105.

[45] Khan,O. (2012). "An Examination of the underlying rational of the profit and loss sharing system with special emphasis on the Mudarabah and Musharakah within the context of Islamic law and Banking" Journal of Finance, Accounting and Management, Vol 3(1) pp. 23 - 31.

[46] Kouser, S. \& Saba. H. (2012). "Islamic bank profitability in an interest rate cycle" International Journal of Islamic Financial services, Vol 4(2) pp 88 - 104.

[47] Loghod, A. H. (2007). "Do Islamic Banks Perform Better than Conventional Banks? Evidence from Gulf Cooperation Council countries"

[48] Liaqat, A. Azmat, A. \& Hamza, K. (2003). "The performance of Islamic Banks and Conventional Banks". Journal of accounting and finance.

[49] Majid, A, Saal. K, David, S. \& Battisti, G. (2011). "The impact of Islamic banking on the cost efficiency and productivity change of Malaysian commercial banks" Appied Economics Vol 43(16) pp. 2033 - 3054.

[50] Majid, A. \& Rulindo. S. (2007). "Impact of financial shocks on Islamic banking in Malaysia during financial crises ". International Journal of Islamic and Middle eastren finance and management contemporary resrearch in business Vol. 3(1) pp. 291-305.

[51] Masruki, R. (2007). "Financial Performance of Malaysian Founder Islamic Banks Versus Conventional Banks" Business and Policy Research, Vol 6(2) pp.67-79.

[52] Massah. S, \& Sayed, A. O. (2015). "Financial Performance of Islamic Banks Versus Conventional Banks in UAE" International journal of information technology and business, Vol 36) pp.87-107.

[53] Metwally, M.M,. (1997). "Differences between the Financial Characteristics of Interest-Free Banks and Conventional Banks" European Business Review, Vol. 97( 2) pp. $92-98$.

[54] Mohammad, S. Hassan, T.\& Bader,M,. (2008) "Efficiency of Conventional and Islamic Banks" Inernational evidence using the sochastic frontier appraoch (SFA) Journal of Islamic economics Banking and Finance, Vol 4(2) pp 107 - 130.

[55] Moin, M. S,. (2008). "Performance of Islamic Banking and Conventional Banking in Pakistan: A Comparative Study" 
[56] Muharrami, A \& Saeed, M. (2008). "An examination of technical, pure technical and scale efficiency in GCC banking". American journal of finance and accountin, Vol 1(2) pp 152 - 166.

[57] Olson, D. \& Zoubi, A.T,. (2007). "Using accounting ratios to distinguish between Islamic and conventional banks in the GCC region" The International Journal of Accounting, Vol. 43(1) pp. 45-65.

[58] Parashar, S.P. \& Venkatesh, J.. (2010). "How did Islamic Banks do during global financial crisis" Banks and Bank Systems, Vol 5 (4) pp. 54-62.

[59] Qayyum, M,. (2007). "Determinant of Islamic Banking profitability during global financial crisis" Journal of banking and finance, Vol 13(1) pp. 65-79.

[60] Rahim, S. \& Hassan, A.N. (2012). "Conventional Banking Profitability Theories in Islamic Banking" Journal of Islamic Banking and Finance, Vol.3(4) pp. 55 -79.

[61] Ramin, B. (2014). "Profitability of Islamic banking in Iron and conventional banking in Turkey" International journal of management and humanity sciences Vol 3(1) pp 70-91.

[62] Riaz, K. (2003) "Book of Islamic Banking and Finance"

[63] Rokhim, G. R,. (2011). "The Stability Comparison between Islamic Banks and Conventional Banks" Evidence in Indonesia 8th International Conference on Islamic Economics and Finance 1

[64] Rosnia, M,. N. (2011). "Financial performance of Malaysian Islamic banks versus conventional banks" Proceeding of the Asia-Pacific Business Research Conference. Kuala Lumpur.

[65] Rosly, S. A,. Abu Bakar, M. A. (2003). "Performance of Islamic and Mainstream Banks in Malaysia" International Journal of Social Economics, Vol 30 (12) pp. 1249-1265.

[66] Ross, S. A,. Westerfield, R.W, \& Jaffe, J. (2005), "Corporate Finance." McGrawHill Inc".

[67] 7th Ed.

[68] Saba, F. Faiza, K. \& Muhammad, I,. (2012). "Developing a system of financial instrument" Journal of Islamic research, Vol 3 (4) pp. 44-56.

[69] Saba, F. \& Sehrish. S. (2012). "Financial Performance of Islamic banks and Conventional Banks of Pakistan". Journal of contemporary resrearch in business,. Vol. 4(1) pp. 21-35.

[70] Safiullah, M. (2010). "Superiority of Conventional and Islamic Banks of Bangladish" International journal of Economics and finance.Vol. 7,(2) pp. 153168.

[71] Saleh, A.S., \& Zeitun, R. (2007). "Islamic Banks in Jordan: Performance and Efficiency Analysis. Review of Islamic Economics" Global economy and finance journal. Vol. 5,(1) pp. 53-72. 
[72] Samad, A,.(1999). "Comparative Efficiency of the Islamic bank malaysia vs conventional banks" IIUM Journal of Economics and Management,. Vol. 7( 1) pp. 1-25.

[73] Samad, A,. (2004). "Performance of Interest-free Islamic banks vis-à-vis Interest-based Conventional Banks of Bahrain". IIUM Journal of Economics and Management,. Vol. 12( 2) pp. 1-15.

[74] Samad,A. \& Hassan,T,. (2004). "The performance of Malaysian Islamic bank". International journal of Islamic financial services Vol 1(3) pp 1-13.

[75] Shaista, W, \& Umadevi, N. G.. (2013). "Comparative study of Islamic banks and Conventional Banks of Bahrain". IIUM Journal of Economics and Management,. Vol. 29( 1) pp. 43-60.

[76] Siraj, K.K,. \& Pillai, P.S,. (2012). "Comparative study on performance of Islamic banks and conventional banks in GCC region" Journal of Applied Finance \& Banking,Vol 2(3) pp 123-161.

[77] Smith, F. \& Rosenthal, D. A. (1995). "Adolescents perception of their risk environment" Journal of Adolescence, Vol 18(2) pp 229-245.

[78] Smith, H. \& Eatough. H. (2012). "Culture and stress a qualitative analyses" International Journal of American anthropologist new series, Vol 74(3) pp 518 529.

[79] Spradely, J. P. (1979). "Culture and stress a qualitative analysis". American anthropologist new series, . Vol. 74(3) pp. 518-529.

[80] Srairi, S.A,. (2010). "Cost and profit efficiency of conventional and Islamic banks in GCC countries". J. Prod. Anal. Vol 34(1) pp 45-62.

[81] Sufian, F,. (2006). "Size and returns to scale of the Islamic banking industry in Malaysia: foreign versus domestic banks". IIUM Journal of Economics and Management, Vol 14(2) pp 147-175.

[82] Storey, L. (2007). "Doing interpretive phenomenological analysis"

[83] Taylor, S. \& Bogdan. C. (1984). "Acculturation and adoption revised" International Journal of cross culture psychology, Vol 30(4) pp 422- 442.

[84] Thorsten, B. Asli, K. \& Quarda, M (2013). "Islamic vs conventional banking ". Business model, efficiency. journal of banking and finance, Vol 37(1) pp 433-447.

[85] Usman, A,. \& Khan, K.M. (2012). "Evaluating the Financial Performance of Islamic and Conventional Banks of Pakistan" International Journal of Business and Social Science, Vol 3(7) pp. 253 - 257.

[86] Van Horne, J. (2005). "Fundamentals of Financial Management".

[87] Vevirita, C. (2011). "Performance Analysis of Indonesian Islamic and Conventional Banks" Journal of Business Finance and Accounting, 6 (3), pp.13-21

[88] Vong, A. and Chan, H. (2009). "Determinants of Bank profitability in Macau" Macau Monetary Research Bulletin, Vol 12 pp. 93 - 113. 
[89] Widago, G \& Ika, H. (2008) "The probem of interest and Islamic banking in a comparative perspective", . Review of middle east economics and finance Vol 1(1) pp. 7 - 70.

[90] Word, H. (2006). "Application of Islamic banking instrument". British food Vol 111(3) pp. $275-295$.

[91] Yudistira, D. (2013). "Efficiency of Islamic banks" An empirical analysis of eighteen banks finance no 0406007.

[92] Zahoor, H. (2013). "Financial Performance of Islamic banks and Conventional Banks of Pakistan". Journal of contemporary resrearch in business, . Vol. 6(1) pp. 53-62.

[93] Zeitun, R. (2012). "Determinants of Islamic and Conventional Banks performance in GCC Countries using panel data analysis" Global Economy and Finance Journal, Vol 5(1) pp. $53-72$. 